\title{
HUBUNGAN TOPOGRAFI WILAYAH TEMPAT TINGGAL IBU MENYUSUI DENGAN KADAR FE DALAM ASI DI SUMATERA BARAT
}

\author{
Yonaniko Dephinto $^{1}$, Dewi Susilawati ${ }^{2}$ \\ S1 Ilmu Keperawatan STIKes Ranah Minang, Indonesia ${ }^{1}$ \\ S1 Kebidanan STIKes MECUBAKTIJAYA Padang, Indonesia ${ }^{2}$ \\ Yona.de.phinto@gmail.com ${ }^{1}$, dewisusilawati39@gmail.com²
}

\begin{abstract}
The quantity and quality of breast milk produced are affected by the food consumed by mothers daily. Judging from the geographical condition and aquatic resources, people in lowland (coastal) blood will consume more animal foods that come from the sea, such as fish, shellfish, and the like. People in the highlands will be more likely to consume food items derived from small livestock such as poultry and the like. This is thought to have an impact on the levels of Fe in breast milk (ASI), considering that the concentration in breast milk is influenced by the mother's diet. This study is an observational study with a cross-sectional comparative design to see the differences in Fe levels in breast milk in breastfeeding mothers who live in the highlands and the lowlands. The sample used is the minimum sample for experimental research and questionnaires, namely 40 respondents for each region. To determine Fe levels, measurements were taken in the LLDIKTI X integrated laboratory using AAS. The FFQ questionnaire was used to determine the nutritional content. Data analysis used the Mann-Whitney nonparametric test. The results of this study were found that in the lowlands more than half of the respondents had a good intake of foods containing iron (70\%) while in the highlands more than half had an intake of foods that contained less iron (57.5\%)., so that there is a regional topographic relationship to iron levels in breast milk for breastfeeding mothers with a pvalue: 0.000
\end{abstract}

Keyword $\quad$ : AAS; breast milk (ASI); topographic; Level of Fe.

\begin{abstract}
ABSTRAK
Kuantitas dan kualitas ASI yang dihasilkan dipengaruhi oleh makanan yang dikonsumsi ibu sehari-hari. Dilihat dari keadaan geografis dan sumber daya perairan, masyarakat di darah dataran rendah ( pantai) akan lebih banyak mengkonsumsi makanan 1 hewani yang berasal dari laut seperti : ikan, kerang dan sejenisnya. Masyarakat di daerah dataran tinggi akan lebih cenderung mengkonsumsi bahan makanan yang berasal dari ternak kecil seperti unggas dan sejenisnya. Hal ini diduga akan berdampak pada kadar Fe dalam Air Susu ibu (ASI), mengingat konsentrasinya dalam ASI dipengaruhi oleh pola konsumsi makanan Ibu. Penelitian ini merupakan penelitian observasional dengan desain cross- sectional comparative untuk melihat perbedaan kadar Fe ASI pada ibu menyusui yang tinggal di dataran tinggi dengan dataran rendah. Sampel yang digunakan adalah sampel minimal untuk penelitian eksperimen dan kuisioner yaitu 40 responden untuk masing-masing wilayah. Untuk mengetahui kadar Fe dilakukan pengukuran di labaratorium terpadu LLDIKTI X dengan menggunanakan AAS. Untuk mengetahui kandungan nutrisi digunakan kuisioner FFQ. Analisis data menggunakan uji nonparametrik Mann-Whitney. Hasil penelitian ini adalah didapatkan bahwa di daerah dataran rendah lebih dari separuh responden mempunyai asupan makanan yang mengandung zat besi yang baik (70\%) sedangkan pada daerah dataran tinggi lebih separuh mempunyai asupan makanan yang mengandung zat besi yang kurang baik $(57,5 \%)$, sehingga terdapat hubungan topografi wilayah terhadap kadar zat besi pada ASI ibu menyusui dengan nilai p-value :0.000.
\end{abstract}

Keyword $\quad$ : AAS, Air Susu Ibu (ASI); topografi; Kadar Fe; 


\section{PENDAHULUAN}

Lingkungan alam, topografi wilayah tempat tinggal sangat mempengaruhi asupan dari masyarakat. Masyarakat yang tinggal di daerah dataran tinggi pada umumnya didominasi oleh hasil-hasil perkebunan, cenderung mengkonsumsi makanan sumber protein nabati. Sedangkan masyarakat di dataran rendah sebagian besar cenderung mengkonsumsi makanan sumber protein hewani yang berasal dari laut dan hasil olahannya (Auliya, Woro and Budiono, 2015).

Asupan nutrisi ini akan mempengaruhi kuantitas dan kualitasi ASI, hal ini disebabkan makanan yang dikonsumsi ibu menyusui sehari-hari. Air susu ibu merupakan sumber nutrisi terbaik bagi bayi dari awal kehidupan 6 bulan pertama sampai dengan usia 2 tahun. ASI mempunyai kadar tinggi nutrisi yaitu, protein, non protein, lemak, oligosakarida, vitamin dan mineral. Selain tinggi nutrisi juga terdapat enzim, hormon, growth factor, dan beberapa zat untuk perlindungan tubuh (Castillo-Castañeda et al., 2019).

ASI mengandung mineral yang lengkap yang mencukupi kebutuhan bayi. Total kebutuhan mineral dalam ASI selama masa laktasi adalah konstan. Kadar mineral dalam ASI tergantung dari diet ibu dan tahapan ASI (Castillo-Castañeda et al., 2019).

Zat besi (Fe) merupakan salah satu mineral yang juga dibutuhkan oleh bayi. Bayi akan terukupi $\mathrm{Fe}$ nya hanya dari air susu ibu dengan pemberian ASI minimal 3 bulan. ASI juga mencukupi lebih dari setengah dari kebutuhan seng setelah pengenalan makanan pendamping bahkan pada tahun kehidupan bayi (Brown et al., 2017).

Menurut penelitian Muluwok et.al di Ethiophia, terdapat perbedaan kadar kalsium $(\mathrm{Ca})$ dan tembaga $(\mathrm{Cu})$ yang signifikan dalam ASI yang tinggal di daerah pegunungan dengan daerah dataran rendah $(p<0,01)$. Perbedaan ini dipengaruhi oleh asupan makanan ibu serta letak geografis tempat tinggal ibu (Maru, Birhanu and Tessema, 2013).

Pada dataran tinggi khususnya daerah di Wilayah kerja Puskesmas Salimpaung Kab. Tanah Datar sumber zat Fe banyak didapatkan kan dari protein nabati seperti tahu, tempe dan kacang-kacangan selain itu sumber Fe juga didapatka sayur-sayuran berwarna hijau seperti bayam, sayur kangkung dan terong. Sedang dataran rendah di Wilayah kerja Puskesmas Seberang Padang kota Padang sumber Zat Fe banyak didapatkan dari protein hewani seperti makanan yang bersumber dari laut karena daerah ini dekat dengan pantai.

Berdasarkan uraian diatas, maka peneliti ingin mengetahui asupan nutris ibu menyusui yang tinggl di dataran tinggi dan dataran rendah dan menganalisis hubungan topografi wilayah tempat tinggal dengan kadar Fe pada ASI

\section{METODE}

Penelitian ini merupakan penelitian observasional dengan desain crosssectional comparative untuk melihat perbedaan kadar $\mathrm{Fe}$ ASI pada ibu menyusui yang tinggal di dataran tinggi dengan dataran rendah. Sampel yang digunakan adalah sampel minimal untuk penelitian eksperimen dan kuisioner yaitu 40 responden untuk masing-masing wilayah. Wilayah yang digunakan adalah wilayah kerja Puskesmas Salimpauang untuk dataran tinggi dan Puskesmas Seberang Padang untuk daaran rendah. Untuk mengetahui kadar $\mathrm{Fe}$ dilakukan pengukuran di labaratorium terpadu LLDIKTI X dengan menggunanakan AAS. Untuk mengetahui kandungan nutrisi digunakan kuisioner FFQ. Analisa data dilakukan dengan sistem komputerisasi. Dalam penelitian ini, peneliti melakukan uji normalitas dengan menggunakan uji Shapiro-Wilk. Pada penelitian ini jika ditemukan data berdistribusi tidak normal, maka analisa data dilanjutkan dengan uji 
alternatifnya, yaitu uji nonparametrik Mann-Whitney. Jika data terdistribusi normal dilakukan uji unpaired T-test. untuk melihat Hubungan tofografi wilayah tempat tinggal terhadap kadar Fe pada air susu ibu

\section{HASIL PENELITIAN}

\section{Analisis Univariat}

\section{Keragaman (Jenis) Bahan makanan sumber Zat Besi (Fe)}

Berdasarkan hasil wawancara kepada 80 responden dengan menggunakan Food Frequenncy Quetionare (FFQ), keragaman konsumsi makanan sumber zat besi (fe) di wilayah dataran tinggi dan dataran rendah adalah sebagai berikut :

Tabel 1. Keragaman (Jenis) Bahan Makanan Sumber Zat Besi (Fe) menurut Tipe Wilayah

\begin{tabular}{clcc}
\hline No & $\begin{array}{l}\text { Bahan makanan } \\
\text { sumber zat besi }\end{array}$ & $\begin{array}{c}\text { Dataran } \\
\text { Rendah }\end{array}$ & $\begin{array}{c}\text { Dataran } \\
\text { Tinggi }\end{array}$ \\
\hline 1. & Susu & $\mathrm{A}$ & $\mathrm{A}$ \\
2. & Keju & $\mathrm{A}$ & $\mathrm{A}$ \\
3. & Yogurt & $\mathrm{A}$ & $\mathrm{C}$ \\
4. & Es krim & $\mathrm{A}$ & $\mathrm{A}$ \\
5. & Susu kedelai & $\mathrm{A}$ & $\mathrm{C}$ \\
6. & Ikan teri kering & $\mathrm{A}$ & $\mathrm{A}$ \\
7. & Ikan bandeng & $\mathrm{A}$ & $\mathrm{E}$ \\
& presto & & \\
8. & Ikan teri segar & $\mathrm{A}$ & $\mathrm{D}$ \\
9. & Sarden (kaleng) & $\mathrm{A}$ & $\mathrm{A}$ \\
10. & Rebon (udang & $\mathrm{A}$ & $\mathrm{C}$ \\
& kecil) segar & & \\
11. & Rebon (udang & $\mathrm{B}$ & $\mathrm{D}$ \\
& besar) segar & & \\
12. & Udang segar & $\mathrm{B}$ & $\mathrm{D}$ \\
13. & Udang kering (ebi) & $\mathrm{A}$ & $\mathrm{C}$ \\
14. & Tiram & $\mathrm{B}$ & $\mathrm{E}$ \\
15. & Kepiting & $\mathrm{B}$ & $\mathrm{E}$ \\
16. & Lobster & $\mathrm{B}$ & $\mathrm{E}$ \\
17. & Cumi- cumi & $\mathrm{A}$ & $\mathrm{D}$ \\
18. & Ikan salmon & $\mathrm{C}$ & $\mathrm{E}$ \\
19. & Tahu & $\mathrm{A}$ & $\mathrm{B}$ \\
20. & Tempe & $\mathrm{A}$ & $\mathrm{B}$ \\
21. & Bayam & $\mathrm{A}$ & $\mathrm{A}$ \\
22. & Buncis & $\mathrm{A}$ & $\mathrm{A}$ \\
23. & Sawi & $\mathrm{A}$ & $\mathrm{A}$ \\
24. & Selada air & $\mathrm{A}$ & $\mathrm{A}$ \\
25. & Kemangi & $\mathrm{A}$ & $\mathrm{A}$ \\
\hline & & & \\
\hline
\end{tabular}

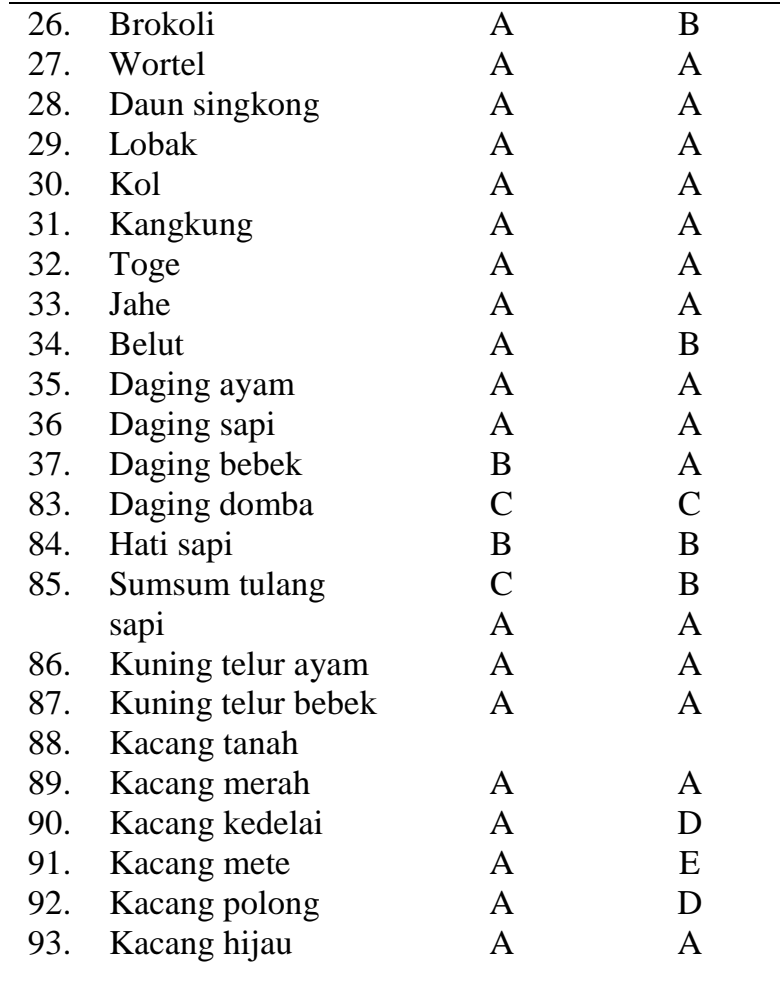

Keterangan :
A: Selalu ada, cukup
B: Kadang Ada, cukup
C: Kadang ada, terbatas
D: Sangat jarang, terbatas
E: Tidak ada

Berdasarkan tabel 2, didapatkan bahwa hampir semua makanan yang mengandung zat besi tersedia di dataran rendah tersedia dalam jumlah cukup. Kadang-kadang juga terdapat jenis makanan seperti tulang sapi, daging domba dan ikan salmon dengan jumlah yang terbatas dikarenakan jenis makanan ini tersedia pada waktu tertentu dan di tempat tertentu sehingga tidak semua responden bisa mengonsumsi jenis makanan ini.

Jenis makanan seperti udang, kepiting, tiram, lobster kadang tersedia dalam jumlah yang cukup di dataran rendah namun dengan harga yang relatif tinggi. sedangkan di dataran tinggi jumlah jenis makanan sangat jarang ditemukan bahkan tidak tersedia sehingga harganya relatif sangat tinggi. sumber makanan yang mengandung zat besi yang paling banyak di temui di daerah dataran tinggi adalah ayam, bebek, 
kacang-kacangan dan sayur-sayuran.

Asupan Zat Besi (Fe) pada Ibu Menyusui di Dataran Rendah dan Dataran Tinggi

Tabel 2. Distribusi frekuensi responden berdasarkan asupan Asupan zat besi di Dataran Rendah dan Dataran Tinggi

\begin{tabular}{lcccc}
\hline \multirow{1}{*}{$\begin{array}{c}\text { Asupan } \\
\text { besi }\end{array}$} & \multicolumn{2}{c}{$\begin{array}{c}\text { Dataran } \\
\text { Rendah }\end{array}$} & \multicolumn{2}{c}{$\begin{array}{c}\text { Dataran } \\
\text { Tinggi }\end{array}$} \\
\cline { 2 - 5 } & f & \% & f & \% \\
\hline Baik & 28 & 70 & 17 & 42.5 \\
Kurang & 12 & 30 & 23 & 57.5 \\
Baik & & & & \\
\hline Jumlah & $\mathbf{4 0}$ & $\mathbf{1 0 0}$ & $\mathbf{4 0}$ & $\mathbf{1 0 0}$ \\
\hline
\end{tabular}

Berdasarkan tabel 3 didapatkan bahwa di daerah dataran rendah lebih dari separuh responden mempunyai asupan makanan yang mengandung zat besi yang baik $(70 \%)$ sedangkan pada daerah dataran tinggi lebih separuh mempunyai asupan makanan yang mengandung zat besi yang kurang baik $(57,5 \%)$.

\section{Analisis Bivariat}

Normalitas Data

Data kadar zat besi menggunakan uji normalitas Shapiro-Wilk karena jumlah sampel masing daerah baik dataran rendah maupun dataran tinggi adalah 40 responden. Data dikatakan berdistribusi normal apabila nilai $\mathrm{p}>0.05$.

Tabel 3 Hasil Ujinormlaitas Kadar Zat besi (Fe) pada ASI di Dataran rendah dan Dataran Tinggi

\begin{tabular}{lcc}
\hline \multicolumn{1}{c}{$\mathbf{1 0}$} & $\begin{array}{c}\text { Mean } \pm \\
\text { SD }\end{array}$ & p value \\
\hline Kadar Fe dalam & $0,296 \pm$ & 0,000 \\
ASI Pada ibu & 0,215 & \\
Menyusui di & & \\
Dataran Rendah & & \\
Kadar Fe dalam & $0.152 \pm$ & 0,000 \\
ASI Pada ibu & 0.126 & \\
Menyusui di & & \\
Dataran Rendah & & \\
\hline
\end{tabular}

Berdasarkan tabel 4 diketahui bahwa hasil uji normalitas kadar $\mathrm{Fe}$ dalam ASI pada Ibu menyusui baik dataran rendah maupun dataran tinggi adalah terdistribusi tidak normal kerena nila $\mathrm{p}<0.05(0,000)$. Analisis statistik selanjunta menggunakan Non Parametrik yaitu Mann-Whitney untuk melihat hubungan topografi wilayah tempat tinggal ibu menyusui dengan kadar Fe.

\section{Hubungan Topografi Wilayah Tempat Tinggal terhadap Kadar Zat Besi (Fe) pada ASI}

Tabel 3. Hubungan Topografi Wilayah Tempat Tinggal terhadap Kadar Zat Besi (Fe) pada ASI

\begin{tabular}{ccc}
\hline Dataran & $\begin{array}{c}\text { Kadar Fe pada } \\
\text { ASI } \\
\text { Mean } \pm \text { SD } \\
(\mathbf{m g} / \mathbf{L})\end{array}$ & $\begin{array}{c}\mathbf{p} \\
\text { value }\end{array}$ \\
& $0,296 \pm 0,215$ & \\
\hline Rendah & 0,000 \\
Tinggi & $0.152 \pm 0.126$ & \\
\hline
\end{tabular}

Berdasarkan tabel 5 didapatkan bahwa rata-rata kadar $\mathrm{Fe}$ dalam ASI pada ibu menyusui lebih tinggi di dataran rendah dibandikan di dataran tinggi. Hasil uji statistik menggunkan uji Mann-Whitney didapatkan ada hubungan topografi wilayah tempat tinggal terhadap kadar Fe dalam ASI pada ibu menyusui yang tinggal di dataran rendah dan dataran tinggi.

\section{PEMBAHASAN}

Asupan Zat Besi (Fe) pada Ibu Menyusui di Dataran Rendah dan Dataran Tinggi

Berdasarkan tabel 3 didapatkan bahwa di daerah dataran rendah lebih dari separuh responden mempunyai asupan makanan yang mengandung zat besi yang baik $(70 \%)$ sedangkan pada daerah dataran tinggi lebih separuh mempunyai asupan makanan yang mengandung zat besi yang kurang baik $(57,5 \%)$.

Lingkungan alam, topografi wilayah 
tempat tinggal sangat mempengaruhi asupan dari masyarakat. Berdasarkan geografis, setiap wilayah mempunyai lingkungan yang berbeda satu sama lain seperti sumber daya, perairan, suhu, cuaca, iklim, kesuburan tanah dan lingkungan kesehatan. Hal ini menyebabkan perbedaan jenis pangan yang dihasilkan ataupun yang tersedia di daerah tersebut.

Masyarakat yang tinggal di dataran rendah sebagian besar mengkonsumsi jenis makanan sumber zat besi seperti daging dan makanan laut yang dapat terpenuhi setiap hari dengan baik, hal ini karena daerah dataran rendah dekat dengan pantai. Masyarakat yang tinggal di daerah dataran tinggi yang sebagian besar adalah petani sawah dan ladang lebih banyak mengkonsumsi makanan sumber kabohidrat dan protein nabati. Jenis bahan makanan mengandung zat besi yang berasal dari laut tidak tersedia setiap hari, walaupun ada jumlahnya jauh lebih sedikit dibandingkan dataran rendah yang pada dasarnya tinggal dekat dengan pantai.

Berdasarkan hasil penelitin ini sebagian besar ibu yang berada di daerah dataran rendah asupan makanan yang banyak dikonsumsi adalah asupan jenis zat besi heme dibandingkan zat besi non heme. Sedangkan pada ibu yang berada di daerah dataran tinggi lebih banyak mengkonsumsi zat besi non heme.

Menurut Isabe Young ed al (2018) bahwa terdapat perbedaan antara asupan zat besi heme dengan non heme terhadap kadar serum feritin. Asupan zat besi heme ditemukan sebagai prediktor independen pada serum feritin. Ini menunjukkan bahwa asupan produk yang mengandung zat besi heme seperti daging (daging sapi, domba, dan ikan) berkontribusi untuk mempertahankan tingkat serum feritin (Young et al., 2018).

Secara teori ada 2 faktor yang mempengaruhi jumlah kadar zat besi dalam tubuh seseorang yaitu faktor langsung dan tidak langsung. Faktor langsungnya berupa adanya infeksi yang disebabkan oleh cacing tambang, malaria dan tubeculosis. Sedangkan secara tidak langsung adalah sosial ekonomi yang rendah (Lestari, Lipoeto and Almurdi, 2018). Pada penelitian ini sebagian besar ibu hanya sebagai Ibu Rumah Tangga (IRT) apalagi yang berada di dataran tinggi $98 \%$ sebagai IRT dimana artinya yang bekerja cuma suami. Jenis pekerjaan dapat menentukan tingkat pendapatan seseorang. Tingkat pendapatan menentukan pangan yang dibeli. Semakin tinggi pendapatan seseorang maka akan mampu membeli jenis makanan yang berkualitas baik seperti daging, udang, sayuran dan buah-buahan.

Selain sosial ekonomi, tingkat pendidikan merupakan salah satu faktor yang dapat mempengaruhi asupan zat besi yang dikonsumsi. Dimana hasil penelitian ini pada dataran tinggi $>50 \%$ berpendidikan SMA tetapi masih banyak juga yang berpendidikan SD dan SMP berbeda dengan di dataran rendah dimana ibu berpendidikan 47\% SMA dan $37 \%$ perguruan tinggi. Menurut Lestari, bahwa tingkat pendidikan dan pengetahuan ibu sangat mempengaruhi terhadap penyusunan pola makan keluarga dan kualitas makanan yang dikonsumsi (Lestari, Lipoeto and Almurdi, 2018).

\section{Hubungan Topografi Wilayah Tempat Tinggal terhadap Kadar Zat Besi (Fe) pada ASI}

Berdasarkan tabel 5 didapatkan bahwa rata-rata kadar $\mathrm{Fe}$ dalam ASI pada ibu menyusui lebih tinggi di dataran rendah dibandikan di dataran tinggi. Hasil uji statistik menggunkan uji Mann-Whitney didapatkan ada hubungan topografi wilayah tempat tinggal terhadap kadar Fe dalam ASI pada ibu menyusui yang tinggal di dataran rendah dan dataran tinggi.

Penelitian yang dilakukan Wang di Cina tentang pengukuran kadar mineral pada ASI dengan menggunakan ferrozine methode, diperoleh kadar Fe pada ASI di China sekitar 0,5 hingga 0,3. Hasil ini sama 
dengan hasil yang di peoleh pada kadar $\mathrm{Fe}$ pada ASi di dataran rendah dan dataran tinggi di Sumatera Barat (Wang et al., 2017).

Hasil penelitian didapatkan rata-rata kosentrasi $\mathrm{Fe}$ di dataran rendah adalah 0.296 sedangkan dataran tinggi 0.152 lebih rendah di banding Hasil penelitian yang dilakukan oleh Patricia Corolina CastilloCastaneda ed al (2018) di Baja California Sur, Mexico di dapatkan rata-rata kosentrasi Fe dalam ASI adalah $0.46 \mathrm{mg} / \mathrm{L}$. Perbedaan rata-rata konsetrasi $\mathrm{Fe}$ pada kedua penelitian ini disebabkan karena pola makan seseorang. Pada penelitian yang dilakukan oleh Patricia Corolina Castillo-Castaneda ed al (2018) populasinya $88 \%$ adalah ibu menyusui yang berada di perkotaan yang geografisnya hampir sama dengan dataran rendah tempat peneliti lakukan, makanya rata-rata kosentrasi $\mathrm{Fe}$ pada dataran rendah tidak terlalu jauh dengan penelitian yang dilakukan oleh Patricia Corolina CastilloCastaneda ed al (Castillo-Castañeda et al., 2019).

Menurut Friel, Kandungan zat besi dalam ASI dianggap rendah dibandingkan $\mathrm{Fe}$ serum pada ibu. Konsentrasi $\mathrm{Fe}$ dalam kolostrum manusia kira-kira $0,8 \mathrm{mg} / \mathrm{L}$, dalam ASI dewasa sekitar 0,2-0,4 mg/L. Menurut Institute of Medicine Dietary Reference Intakes (DRIs), bahwa berdasarkan rata-rata konsentrasi $\mathrm{Fe}$ pada ASI kebutuhaan bayi akan zat besi usia 6 bulan adalah 0,27 mg/hari (Friel, Qasem and Cai, 2018). Sama halnya dengan hasil penelitian ini terutama di daerah dataran rendah dimana didapatkan rata-rata konsentrasi $\mathrm{Fe}$ nya dalah 0,296 mg/L, artinya kadar fe dalam ASI di dataran rendah mencukupi kebutuhan zat besi pada bayi sampai usia 6 bulan. Tetapi pada ibu di dataran tinggi belum mencukupi karena rata-rata konsentrasi zat besi 0.0152 .

Hasi penelitian ini menunjukkan bahwa rata-rata kadar $\mathrm{Fe}$ dalam ASI di dataran rendah lebih tinggi di bandingkan dataran tinggi ini disebabkan karena pada ibu yang berada di dataran rendah lebih banyak mengkonsumsi zat besi heme (hewani) seperti daging (daging sapi, domba dan jenis makanan laut terutama ikan) dibandingkan zat besi non-heme (nabati). Menurut Isabe Young ed al (2018), bahwa kapasitas penyerapan zat besi heme lebih tinggi dibandingkan zat besi non heme. Banyak faktor yang mempengaruhi penyerapan zat non-heme yaitu seperti zat besi non-heme akan lebih meingkat penyerapannya jika di konsumsi berbarangan dengan asam askorbat atau sebaliknya di hambat oleh makanan yang mengandung asam fitra yang di temukan pada makanan berserat dimana akan mengikat zat besi non-heme di usus sehingga membatasi penyerapannya (Young et al., 2018).

Asupan serapan zat besi yang tidak adekuat dapat menyebabkan kekurangan zat besi seperti mengkonsumsi makanan yang kandungan zat besinya kurang (makan tinggi serat, rendah vitamin $\mathrm{C}$ dan rendah daging) (Lestari, Lipoeto and Almurdi, 2018). Sama halnya yang dikonsumsi oleh ibu yang berada di dataran tinggi, sehingga penyebabkan kurangnya zat besi dalam ASI.

Kadar zat besi ditentukan oleh asupan zat besi pada tubuh. Pada penelitian ini kadar zat besi lebih tinggi pada dataran rendah di bandingkan pada dataran tinggi ini di sebabkan karena asupan makanan yang amsuk kedalam tubuh ibu. Penelitian ini sama dengan penelitian yang dilakukan oleh Anggraini dimana hasilnya kadar ferritin lebih tinggi pada kelompok yang mengonsumsi non vegetarian dibandingan vegetarian (Anggraini, Lestariana and Susetyowati, 2015).

Makanan nabati banyak mengandung zat besi, namun zat besi yang terdapat dalam makanan nabati adalah zat besi non heme yang sesungguhnya lebih sulit diserap di usus dibandikan makanan hewani yang banyak mengandung zat besi. Zat besi yang terdapat dalam kananan hewani disebut zat besi heme yang mudah diserap di usus (Anggraini, Lestariana and Susetyowati, 
2015).

\section{SIMPULAN}

Asupan zat besi pada ASI ibu menyusui lebih tinggi di dataran rendah dibandingkan ibu yang berada di dataran tinggi sehingga terdapat hubungan topografi wilayah terhadap kadar zat besi pada ASI ibu menyusui. Kadar zat besi pada ASI ibu menyusui lebih tinggi pada ibu yang tinggal di dataran rendah dibandingkan ibu di dataran tinggi.

\section{DAFTAR PUSTAKA}

Anggraini, L., Lestariana, W. and Susetyowati, S. (2015) 'Asupan gizi dan status gizi vegetarian pada komunitas vegetarian di Yogyakarta', Jurnal Gizi Klinik Indonesia, 11(4), p. 143. doi: 10.22146/ijen.22986.

Auliya, C., Woro, O. and Budiono, I. (2015) 'Profil Status Gizi Balita Ditinjau Dari Topografi Wilayah Tempat Tinggal (Studi Di Wilayah Pantai Dan Wilayah Punggung Bukit Kabupaten Jepara)', Unnes Journal of Public Health., 4(2), pp. 108-116. doi: 10.15294/ujph.v4i2.5739.

Brown, K. H. et al. (2017) 'Dietary Intervention Strategies to Enhance Zinc Nutrition: Promotion and Support of Breastfeeding for Infants and Young Children', HHS Public Access, 30(1), pp. 144-177. doi:
10.1177/15648265090301S108.

Castillo-Castañeda, P. C. et al. (2019)

'Micronutrient content and antioxidant enzyme activities in human breast milk', Journal of Trace Elements in Medicine and Biology. Elsevier GmbH., 51, pp. 36-41. doi: 10.1016/j.jtemb.2018.09.008.

Friel, J., Qasem, W. and Cai, C. (2018) 'Iron and the breastfed infant', Antioxidants, 7(4), pp. 2-9. doi: 10.3390/antiox 7040054.

Lestari, I. P., Lipoeto, N. I. and Almurdi, A. (2018) 'Hubungan Konsumsi Zat Besi dengan Kejadian Anemia pada Murid SMP Negeri 27 Padang', Jurnal Kesehatan Andalas, 6(3), p. 507. doi: 10.25077/jka.v6i3.730.

Maru, M., Birhanu, T. and Tessema, D. A. (2013) 'Calcium, magnesium, iron, zinc and copper, compositions of human milk from populations with cereal and "enset" based diets.', Ethiopian journal of health sciences, 23(2), pp. 90-97.

Wang, H. J. et al. (2017) 'Sialic acid and iron content in breastmilk of Chinese lactating women', Indian Pediatrics, 54(12), pp. 1029-1031. doi: 10.1007/s13312-017-1206-z.

Young, I. et al. (2018) 'Association between haem and non-haem iron intake and serum Ferritin in healthy young women', Nutrients, 10(1), pp. 1-13. doi: 10.3390/nu10010081. 